\title{
Form, function and physics: the ecology of biogenic stabilisation
}

\author{
David M. Paterson ${ }^{1}$ (1) - Julie A. Hope ${ }^{1,2,3} \cdot$ Joseph Kenworthy ${ }^{1,4} \cdot$ Catherine L. Biles $^{1,5} \cdot$ Sabine U. Gerbersdorf ${ }^{2}$
}

Received: 21 September 2017 / Accepted: 13 April 2018

(C) The Author(s) 2018

\begin{abstract}
Purpose The objective of this work is to better understand the role that biological mediation plays in the behaviour of fine sediments. This research is supported by developments in ecological theory recognising organisms as "ecosystem engineers" and associated discussion of "niche construction", suggesting an evolutionary role for habitat modification by biological action. In addition, there is acknowledgement from engineering disciplines that something is missing from fine sediment transport predictions.

Materials and methods Advances in technology continue to improve our ability to examine the small-scale 2D processes with large-scale effects in natural environments. Advanced molecular tools can be combined with state-of-the-art field and laboratory techniques to allow the discrimination of microbial biodiversity and the examination of their metabolic contribution to ecosystem function. This in turn can be related to highly resolved measurements and visualisation of flow dynamics.

Results and discussion Recent laboratory and field work have led to a paradigm shift whereby hydraulic research has to embrace biology and biogeochemistry to unravel the highly complex issues around on fine sediment dynamics. Examples are provided illustrating traditional and more recent approaches including using multiple stressors in fully factorial designs in both the laboratory and the field to highlight the complexity of the interaction between biology and sediment dynamics in time and space. The next phase is likely to rely on advances in molecular analysis, metagenomics and metabolomics, to assess the functional role of microbial assemblages in sediment behaviour, including the nature and rate of polymer production by bacteria, the mechanism of their influence on sediment behaviour.

Conclusions To fully understand how aquatic habitats will adjust to environmental change and to support the provision of various ecosystem services, we require a holistic approach. We must consider all aspects that control the distribution of sediment and the erosion-transport-deposition-consolidation cycle including biological and chemical processes, not just the physical. In particular, the role of microbial assemblages is now recognised as a significant factor deserving greater attention across disciplines.
\end{abstract}

Keywords Biofilm $\cdot$ Biostabilisation $\cdot$ Ecosystem engineering $\cdot$ EPS $\cdot$ ETDC cycle $\cdot$ Metagenomics

Responsible editor: Gudrun Hillebrand

David M. Paterson

dp1@st-andrews.ac.uk

1 Scottish Ocean Institute, School of Biology, University of St Andrews, East Sands, St Andrews KY16 8LB, UK

2 Institute for Modelling Hydraulic and Environmental Systems, University of Stuttgart, Pfaffenwaldring 61,

70550 Stuttgart, Germany

3 Institute of Marine Science, University of Auckland, Auckland, New Zealand

4 Roscoff Marine Station, UPMC CNRS, Place Georges Teissier, 29680 Roscoff, France

5 The University of Sheffield, Western Bank, Sheffield S10 2TN, UK

\section{Introduction}

\subsection{Niche separation and ecosystem engineering}

The earliest visible remnants of organismal life on Earth come from the fossil record of bacterial remains and the laminated deposits preserved in early rock formations (cf 3.5 billon years BP, Altermann and Józef 2003). The laminated fossils, known as stromatolites, are clear early evidence of life but also of biological impact on sediment dynamics (Paterson et al. 2008). Palaeoecologists often debate the formation of ancient microbial remains, biofilms and mats and what these remnants reveal about the palaeoclimatological, hydrological and sedimentological conditions in those ancient environments when the material was first preserved (Noffke and Paterson 2008). There is evidence that these early bacterial assemblages were 
capable of trapping and binding sediments (Altermann 2008), helping to create one of the first recognisable ecosystems on the planet, a phenomenon that is also observed in contemporary studies that reconstruct and understand ancient sediments (Krumbein et al. 1994). The ability of organisms to affect their environment is well-known (Paterson 1997) and often described as "ecosystem engineering" (Jones et al. 1994). However, the examples of ecosystem engineers that are given are often larger charismatic species (elephants, beavers, otters, etc.) while organisms such as bacteria and protists (including the algae) equally, if not more important, attract less attention (Boogert et al. 2006; Gerbersdorf et al. 2009). There is a further interesting twist to the "ecosystem engineering" debate. Some evolutionary theorists consider that the alteration of the environment by organisms should, in itself, be recognised as an evolutionary pressure. For example, the stabilisation of fine sediments at the sediment-water interface allows biogeochemical gradients to become established. This initiates a change in local conditions (niche separation) that helps to promote specialisation among bacteria that, in combination with the ability to genetically "fix" those changes (improved fitness), drives the evolutionary process. The development of this theory, termed "niche construction" (Laland et al. 1999), is somewhat controversial, but seems a logical extension from the acceptance of the widespread nature of the "ecosystem engineering" process. While the debate surrounding theories of "ecosystem engineering" and "niche construction" continues, there is an increasing concern among environmental scientists regarding the fundamental question: "To what extent can the impact of biological processes be taken into account when predicting the erosion, transport, deposition and consolidation cycle (ETDC) of natural sediments"?

\subsection{Is sediment biostabilisation important?}

Efforts to answer this question have been accelerating since the early work of Manzenrieder (1983), showing that cohesive natural sediments did not conform to the predictions of the Shields curve (Black et al. 2002; Tolhurst et al. 2009). While engineers and biologists approached this issue in a variety of ways, a growing body of evidence has gathered in the literature to support the conclusion that the influence of biology is largely through bioturbation and biological sediment cohesion - the former has a destabilising effect, while the latter stabilises surface sediments (e.g. Le Hir et al. 2007). Much of this early "biostabilisation" research was published in the biological literature (Krumbein et al. 1994; Paterson 1994) with slower uptake in the more physical literature until more recent studies (Grabowski et al. 2010; Malarkey et al. 2015; Chen et al. 2017). While negative effects on the erosional behaviour of fine sediments are mainly attributed to macrofauna (e.g. de Deckere et al. 2001), biological cohesion is largely through the production of extracellular polymeric substances (EPS) by microbes, meio- and macrofauna (Paterson and Black 1999). In terms of microbes, their attachment and the further development of a biofilm are the prerequisite for cell-cell and cell-substratum adhesion via cell adhesion molecules (CAMs) as well as for EPS secretion permeating the void space. While individual bacterial and microalgae cells are unlikely to have significant measurable effect on the behaviour of the whole system, once conditions are suitable, cells proliferate rapidly and grow in concert (e.g. Black et al. 2002). Thereby, biofilm growth is mutually dependent on a variety of abiotic and biotic conditions (reviewed in Gerbersdorf and Wieprecht 2015) to eventually change sediment characteristics (Lubarsky et al. 2010, Chen et al. 2017).

First indications of these microbial-induced shifts in mechanical properties of fine sediments were given almost half a century ago by Meadows and Anderson (1969). Since then, many studies focused on surface erosion threshold, often in context of the biogeochemical fluxes at the sediment-water interface (e.g. Sutherland et al. 1998; Amos et al. 1998; Tolhurst et al. 2008; Fagherazzi et al. 2014). Apart from the majority of past studies being performed in the intertidal areas, there is now also evidence of the importance of biostabilisation in fluvial systems (e.g. Schmidt et al. 2015, 2016; Thom et al. 2015). Beyond the microbial impact on surface stability, the lateral movement of sediment can be severely influenced during bedform development and migration (Friend et al. 2008; Hagadorn and McDowell 2012; Malarkey et al. 2015; Parsons et al. 2016) but this phenomenon is also highly significant for the erosion thresholds of deeper sediment layers (Gerbersdorf et al. 2007; Chen et al. 2017). Last but not least, EPS has been shown to promote the aggregation and deposition of suspended material (Eisma 1986; Mietta et al. 2009; Manning et al. 2010). Consequently, microbes and their biofilm matrix impact the whole ETDC (erosion-transport-deposition-consolidation) cycle of fine sediments. This has further implications, for instance, the transport and storage of nutrients, xenobiotic compounds, pollutants such as heavy metals and even pathogens such as Escherichia coli that are often associated with fine sediments (Droppo et al. 2009; Pachepsky and Shelton 2011; Gerbersdorf et al. 2015). Understanding the factors that mediate sediment transport becomes increasingly important with future climate scenarios such as sea level rise, increased storm events and the erosion of coastal sediments (Grabowski et al. 2011).

As modelling techniques become more sophisticated, questions concerning the difference between the predicted and measured sediment behaviour will arise more frequently. Integrative interdisciplinary approaches such as the ecosystem approach (see below) to understanding the ETDC cycle are emerging in order to incorporate all aspects into transport models (Le Hir et al. 2007). This change in approach is apparent from the increasing acceptance of articles on the 
biological mediation of sediment dynamics in the physical disciplines and literature (Malarkey et al. 2015; Parsons et al. 2016; Chen et al. 2017) and a more holistic approach to understanding the relationship between sediment water and biota.

\section{The ecosystem approach}

Examination of natural sediment systems can be categorised into three broad approaches: laboratory experimentation, field experimentation and field observation. All have required an important change in ethos and advances in technology to support improved understanding of the natural world. For example, across many spheres of environmental management, the concept of the "ecosystem approach" has been gaining ground. The "ecosystem approach" has many definitions (Apitz et al. 2006) but fundamentally requires a more holistic understanding of biotic and abiotic interactions that drive the ecological dynamics of a given habitat. This means including and understanding the interactions between the biology, physics, biogeochemistry and fluid mechanics of the system and the combination of these factors and processes which ultimately deliver goods and services valued by humans (Beaumont et al. 2007). The need for research at this interface has been recognised early on by engineers, biologists, geomorphologists and sedimentologists, but there is still a need to coordinate disciplines requiring adoption of mutually accepted methods, approaches and scales of investigations (Hannah et al. 2004; Rice et al. 2010). Despite increasing research efforts combining the relevant disciplines (e.g. Graba et al. 2010; Vignaga et al. 2012), there is still a paucity of information about the important flow-biofilm-sediment troika. From the hydrodynamic perspective, mean velocity values from the water column do not represent turbulence patterns and flow that vary significantly at biofilm scale (Moulin and Eiff 2012; Hodl et al. 2014). On the other hand, research focusing on biofilm architecture and composition in relation to flow usually involves single-species biofilm mostly grown in miniature flow cells under non-natural flow conditions (Pereira et al. 2002; Wagner et al. 2010). This example illustrates that biostabilisation research still requires fundamental input from various perspectives to investigate the most relevant conditions and processes to deliver variables that would allow implementation in models at a later stage.

In recent times, there has been some progress in implementing biological cohesion and adhesion forces into sediment transport models. However, whether it is about mimicking cohesion (Lick et al. 2004) or adding a combination of cohesion and adhesion coefficients (Righetti and Lucarelli 2007), there is still a significant lack of suitable data and appropriate measuring devices to strengthen the empirical dataset and validate the models (Grabowski et al. 2011).
Moreover, the complex nature of biological processes and the numerous variables identified (Paterson 1997) would increase model complexity beyond reliability so the challenge to the biological community is to detect and parameterise a limited number of master variables that can be used in models. Last but not least, we are just beginning to understand the significance of varying flow conditions and the need to identify turbulence patterns that are most relevant for biofilm growth, functionality and sediment fluxes (Decrop et al. 2015; Koca et al. 2017). With the development of high resolution and high speed methods (e.g. modern particle image velocimetry (PIV)) and precision tomography (Wheatland et al. 2017), improved information on microscale fluid mechanics relating to biofilm responses, biostabilisation and bed properties are now possible.

There is still the difficulty of fully recreating natural conditions in the laboratory. This limitation promotes the practice of field measurements/observations of sediment erosion and dynamics to compliment laboratory studies. Of course, fieldwork cannot, and should not, replace laboratory studies but there is a balance to be struck and, at present, there is still a dearth of detailed high-quality fieldwork data to place laboratory studies in context and validate developing models.

\section{Laboratory experimentation}

\subsection{The paradigm shift concerning biota in sediment research}

Historically, the effect of biology was removed from test systems. Relationships such as the Shields curve (Shields 1936) were based on experiments conducted in laboratories with sediments that had been cleaned and sorted. This relationship suffers from a number of shortcomings as a predictive tool since processes such as self-weight consolidation and biological effects (biostabilisation and bioturbation) are not included. Some researchers (Nowell et al. 1981; Manzenrieder 1983; Parchure and Mehta 1985) have studied the influence of biology on the erosional characteristics of natural sediments, but their work was peripheral to the main quest to develop a theoretical understanding of sediment dynamics. In the last few decades, many engineers have recognised the importance of biological processes ranging from coastal protection (mangroves, salt marshes seagrasses) to better understanding of floc dynamics and structure (Wheatland et al. 2017) and the ETDC cycle. However, particle-flow interactions are complex and are being addressed by theoretical (Violeau 2012) and practical advances (Unadkat et al. 2009) and there are other issues in terms of revealing the complexity of turbulence structures in flow and their effects on particle behaviour that also requires advances in understanding and should be a rich vein of cooperative research. While early progress was 
hindered by the lack of suitable methodologies to apply to natural systems, an initial reluctance to bring the field into the laboratory and a lack of desire or resources to simulate the natural environment has now changed, and there is now an increasing emphasis on "in situ" work (Andersen et al. 2010) and combined "field and laboratory" (Malarkey et al. 2015; Parsons et al. 2016; Schmidt et al. 2016) and "empirical and modelling" work (Orvain et al. 2006). However, research at this sediment-biota-water interface also requires a breadth of knowledge from multiple disciplines, resulting in oversimplified or inappropriate conditions reducing the value of the data. While engineers often employ large-scale flume experiments that mimic natural hydraulic regimes, conditions for the inclusion of biology (e.g. light and nutrients), this is logistically demanding and a specialised approach is required (e.g. Vignaga et al. 2012; Spencer et al. 2016). Biologists, on the other hand, may wish to observe biofilm development on the nano- to microscale and often grow biofilm in miniature flume cells under strictly laminar non-natural flow conditions (e.g. Manz et al. 2005; Hodl et al. 2014), a limited approach in terms of sediment dynamics. There is now an increasing awareness that research into natural sediment transport dynamics has to embrace physics, biology and biogeochemistry to unravel the highly complex issues around fine sediment dynamics in ecohydraulic research (Rice et al. 2010).

\subsection{Examples of interdisciplinary research}

Interdisciplinary efforts are being developed as exemplified in several recent laboratory experiments jointly established by engineers and natural scientists. One example is the construction of large recirculating flumes that - by size - mimic natural flow more closely and remove wall effects adjacent to the test section while at the same time, the requirements of the biotic component (e.g. light, temperature, nutrients) are fully considered (Schmidt et al. 2015). The combination of quasinatural biofilm growth along with controllable settings of abiotic conditions can provide insight as to the importance of single variables, to understand underlying processes in detail and enable predictions for future scenarios, a perfect example where laboratory work can successfully translate meaningful results into the field. These experiments performed within the DFG project "sediment entrainment and flocculation" (GE 1932/3-1 and 3-2) highlighted the importance of fine sediment biostabilisation in freshwaters, unraveled the influence of light and hydrodynamics and most importantly demonstrated the seasonality of the microbial stabilisation with significantly higher values in spring (Thom et al. 2015; Schmidt et al. 2016; and 2017). The results, besides developing knowledge on fundamental processes, may have implications for sediment management strategies in waterways and reservoirs such as flushing operations.
Apart from developing natural biofilms on an inert substratum, other interdisciplinary studies have taken natural sediments into the laboratory or created model "sediment systems" designed to test biological effects (Malarkey et al. 2015; Parsons et al. 2016). In this context, not only the role of biological influence on sediment erosion thresholds or stability is important, but also post-erosional processes, such as particle/organic/inorganic matter aggregation. This is a frontier where field studies can be supported by in-depth investigations in the laboratory. For example, recent investigations have used advances in 3D imaging technology to reveal the nanoscale properties of individual flocs (Wheatland et al. 2017). This study has shown that even at this small scale, the biological properties and the bacterial community that inhabit flocs can drastically influence suspended particulate matter (SPM) behaviour, altering characteristics such as settling velocity, size shape and porosity (Manning et al. 2010). This information is critical for our understanding of suspended sediment transport, model predictions and coastal management.

\subsection{The meaning of spatial and temporal scaling}

Ecohydraulic research in Europe has been supported by the EU-HYDRALAB initiative (http://www.hydralab.eu) which offers access to 18 large-scale facilities such as wave flumes, basins for coastal research or environmental hydraulic facilities. Several projects have already been conducted at the "Total Environment Simulator" in Hull (length 16 m, width $6 \mathrm{~m}$ ). One project examined the reciprocal role of hydrodynamic forcing and microbial colonisation in a groyne field while applying ADV, URS, MagPI and biochemical as well as community analysis (Hydralab Gerbersdorf et al. pers. comm). Hydrodynamic forcing led to particle sorting in the groyne field, characterised by a developing gradient from coarser to finer particles towards its inner circle. However, the dominant epipelic diatom, Nitzschia palea (Fig. 1a), settled equally over the bed surface, and the sediment stability increased up to 12 times over 3 weeks (Fig. 1b). These facilities were also utilised as part of the NERC funded COHesive BEDforms (COHBED) project (NE/1027223/1), where the role of biological and physical cohesion on bedform development has been investigated (Schindler et al. 2015; Parsons et al. 2016). Another particularly remarkable effort to examine natural systems under laboratory flume conditions was the dissection, transport and re-assembling of a whole area of natural salt marsh (Möller et al. 2014) into what the authors claim is the largest open-access flume system in the world ( $310 \mathrm{~m}$ length by $5 \mathrm{~m}$ width and $7 \mathrm{~m}$ in depth). The result demonstrated the importance of vegetation in reducing wave energy and the resilience of the marsh despite shearing of individual plant elements. This investigation would be difficult in the field, and the results may also be scale-dependant 
Fig. 1 a The development of surface adhesion as demonstrated by the force required to remove ferrous particles (MagPI technique, force proportional to current in amperes) over the 3 weeks of incubation of sediment from three different areas (Sites: Field 1, Field 4 and Field V of different grain sizes) within the groyne field. (b) Microscopic image(magnification 400x) of the dominant diatom species, Nitzschia palea (courtesy: Dr. Jane Reed, University of Hull)
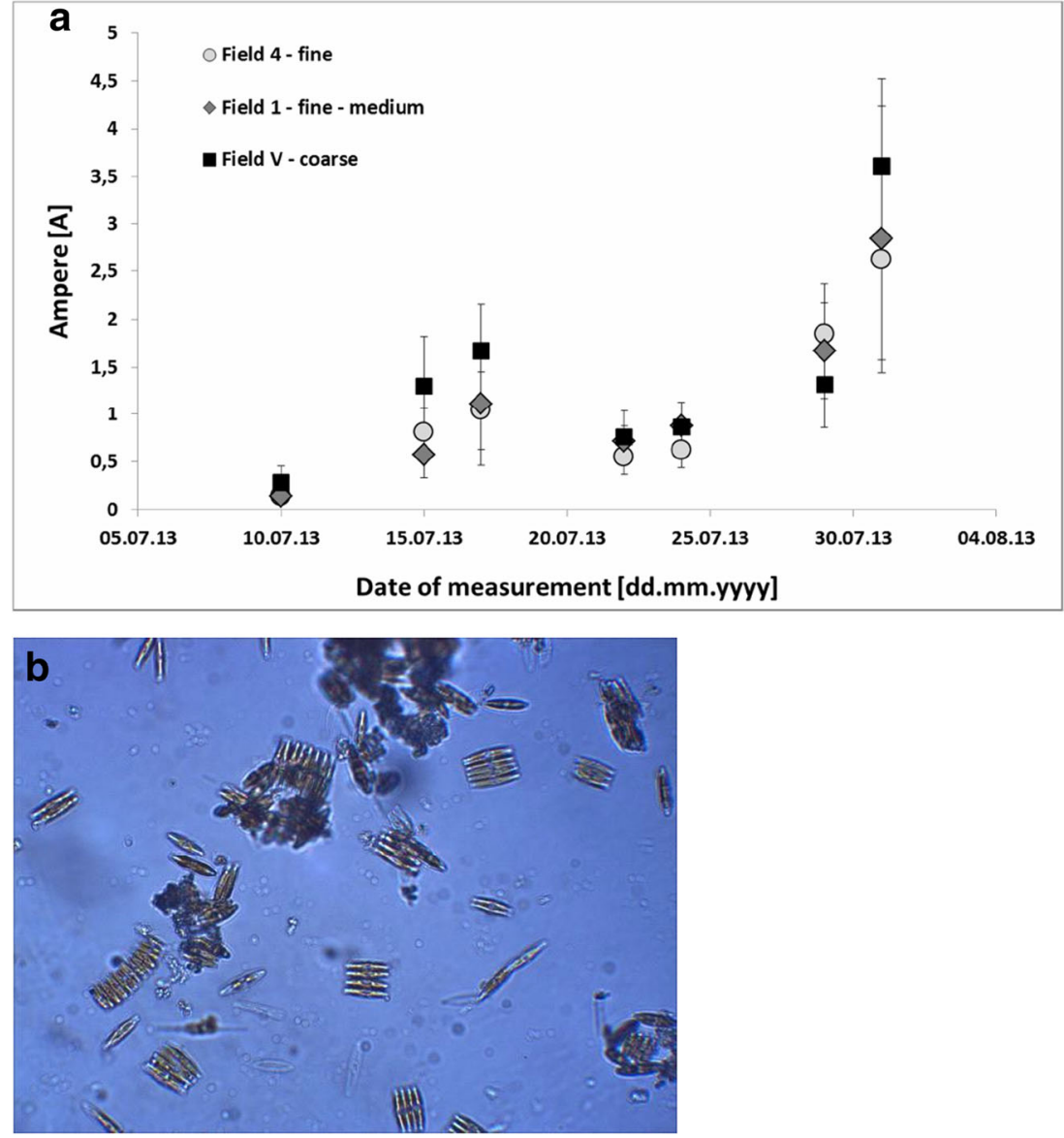

and the outcome may be different if conducted within smaller flumes; indeed, the scale of experiments both spatially and temporally is often an important consideration (Chapman et al. 2010). While biofilms are a well-studied phenomenon (Characklis and Marshall 1990), the temporal scale is hardly considered since the majority of studies concern mono-species cultures of medical relevance and focus on molecular interactions at the cell surface in the first hours of settlement as well as infection and antibiotic resistance (e.g. Aanensen et al. 2016). Furthermore, in ecological research, biofilms are rarely investigated at their fully matured stage, for instance, in the above-mentioned flumes of Schmidt et al. (2015) and Thom et al. (2015). In addition, the biofilm is usually restricted to microorganisms. Natural successions characterised by the later settlement of metazoan algae, mussels or snails and grazing macroorganisms are generally excluded. Despite these limitations, laboratory investigations provide essential information on the biological drivers in particular systems. As we increase our understanding of the mechanisms behind various ecosystem functions and how they relate to sediment dynamics, we move one step closer to linking the small-scale biological effects to large-scale transport models (Borsje et al. 2008). This, however, requires understanding of the processes across several spatial scales and under various conditions. These studies illustrate the recent move towards larger and more complex experiments, which more closely replicate natural conditions or the benthic communities of the system.

\subsection{How to develop laboratory experiments}

The data gained with complex laboratory experiments marks a welcome development towards interdisciplinary research and a step towards biological effects being parameterised in sediment dynamics models. Nevertheless, the cost and logistical efforts behind much of this work are immense and so unlikely to be widely repeated; therefore, efficient use of resources and cooperative work are important. The aim of laboratory experiments is usually to reduce or control the number of variables that might influence an outcome, whereas in natural mesocosms or in the field, the number of variables increases and the interactions become extremely complex (Thrush et al. 2008; Tolhurst et al. 2009). As a consequence, the nature of the relationships between factors is increasingly multifaceted in the latter scenarios. A clear example of this can be observed from the Shields curve predictions, which implies a relationship between particle size and the critical stress for erosion. This may seem straightforward from the original investigation: under laboratory conditions; using a set constant 
temperature; highly controlled flow (stress); a wellcharacterised fluid; and "clean" well-sorted sediments. The outcome is reasonably repeatable, even with the addition of a mineral proxy (kaolin) for the cohesive fraction (Paterson and Black 1999). However, in nature, few of these conditions apply (Black et al. 2002) and therefore the predictions are often inaccurate. Not only does the temperature and viscosity of the medium vary (salinity), even rainfall on the surface of exposed intertidal flats alters the bed response to erosion (Tolhurst et al. 2006). The physical properties of natural sediments are also variable; they contain mixtures of particles sizes, varying cohesive fractions or mineral types. Furthermore, natural sediments are colonised by both macrofauna and microorganisms that change the bed properties and behaviour under erosive stress (Paterson 1994; Gerbersdorf et al. 2009; Passarelli et al. 2012). It is therefore not surprising that the relationship between grain size and sediment erosion loses predictive power under natural conditions, and this is the area where interdisciplinary investigations are required.

\section{Field observations}

The challenge of understanding natural sediment dynamics is clearly being addressed and changes in technology are supporting this rapid development. In situ technology and data capture now allow the analysis of water motion, particle tracking, floc dynamics and bedform properties to be remotely assessed in real time. This combined approach has allowed detailed, high-resolution analysis of the changing nature of natural beds but also allows for the correlation between these physical processes and other variables (biological and biogeochemical) from samples collected during the same period. For example, the COHBED project combined multidisciplinary expertise and techniques to investigate the influence of physical, chemical and biological processes on the formation and migration of bedforms in the field. High-resolution ripple profiles, laser scans and ADV data were employed along with biogeochemical samples from the bed, allowing the biological cohesion to be related to the morphological changes in bedforms. In addition, the floc characteristics (settling velocity, size, effective density, etc.) were related to key biological properties from the same SPM samples (Manning et al. 2010; Hope 2016).

Field campaigns were complimented with further simplified flume studies to allow the effect of biostabilisation to be determined for both cohesive (Parsons et al. 2016) and non-cohesive sediments (Malarkey et al. 2015). Increasingly, it is acknowledged that biological effects, often through the accumulation of extracellular polymeric substances (EPS), not only influence the biostabilisation of sediment beds, but mediate the transport and deposition of fine material once it is resuspended. Imaging techniques such as low temperature scanning electron microscopy (LTSEM, Fig. 2) of flash frozen intact sediments or the LabSFloc-2 system (Manning et al. 2010) illustrate the textural and community components of the system or in situ floc settling velocity and effective density. Floc characteristics were related to the acidic fraction of polymeric substances (APS), quantified by cytochemical staining techniques, with the temporal variation in both evaluated (Hope 2016). Hope found APS concentrations were a better predictor of the floc effective density than the SPM concentration (Hope 2016). Indeed, this work supports Wheatland et al. (2017), who visualised this biological contribution. Organic quantification methods may therefore provide a good predictor variable for floc behaviour and settling velocity. The results undoubtedly have important implications for future models, since SPM concentration and turbulence are often considered to mediate flocculation and depositional behaviour alone (Eisma 1986) while biological properties are, more often than not, excluded, but undoubtedly increase the cohesive force between particles (Mietta et al. 2009).

\section{Field experimentation}

While both laboratory studies and field observations are effective techniques for monitoring the environment, they cannot always be utilised to successfully predict the implications of environmental change. Sedimentary habitats are subject to multiple stressors of both anthropogenic and climatic origin (Christensen et al. 2006; Kenworthy et al. 2016), the intensities of which are likely to increase in the coming decades (Halpern et al. 2008). The effect of these changes on sediment dynamics remains difficult to predict. Laboratory studies can and have been used effectively to analyse the impacts of stressors (e.g. Hicks et al. 2011; Thom et al. 2015); however, they do this in isolation from natural habitats and communities. It is difficult for researchers to take full account of the complete environmental and biological context (Hewitt et al. 2007); thus, the role these attributes play in mediating stressor impacts is not fully understood (Bishop and Kelaher 2013). Natural environments tend to be heterogeneous, whereas mesocosm or laboratory studies are generally controlled homogeneous environments (Dyson et al. 2007). Natural heterogeneity has been observed to buffer against stressor effects (Godbold et al. 2011) or negate patterns observed under laboratory conditions (Bulling et al. 2008).

Stressors in ecological systems rarely occur singularly (Crane et al. 2007; Halpern et al. 2008) and may overlap in time and space (Kenworthy et al. 2016). Furthermore, multiple stressors will often act in a cumulative manner that cannot be predicted from simply adding their combined effects (Crane et al. 2007). As natural habitats are subject 

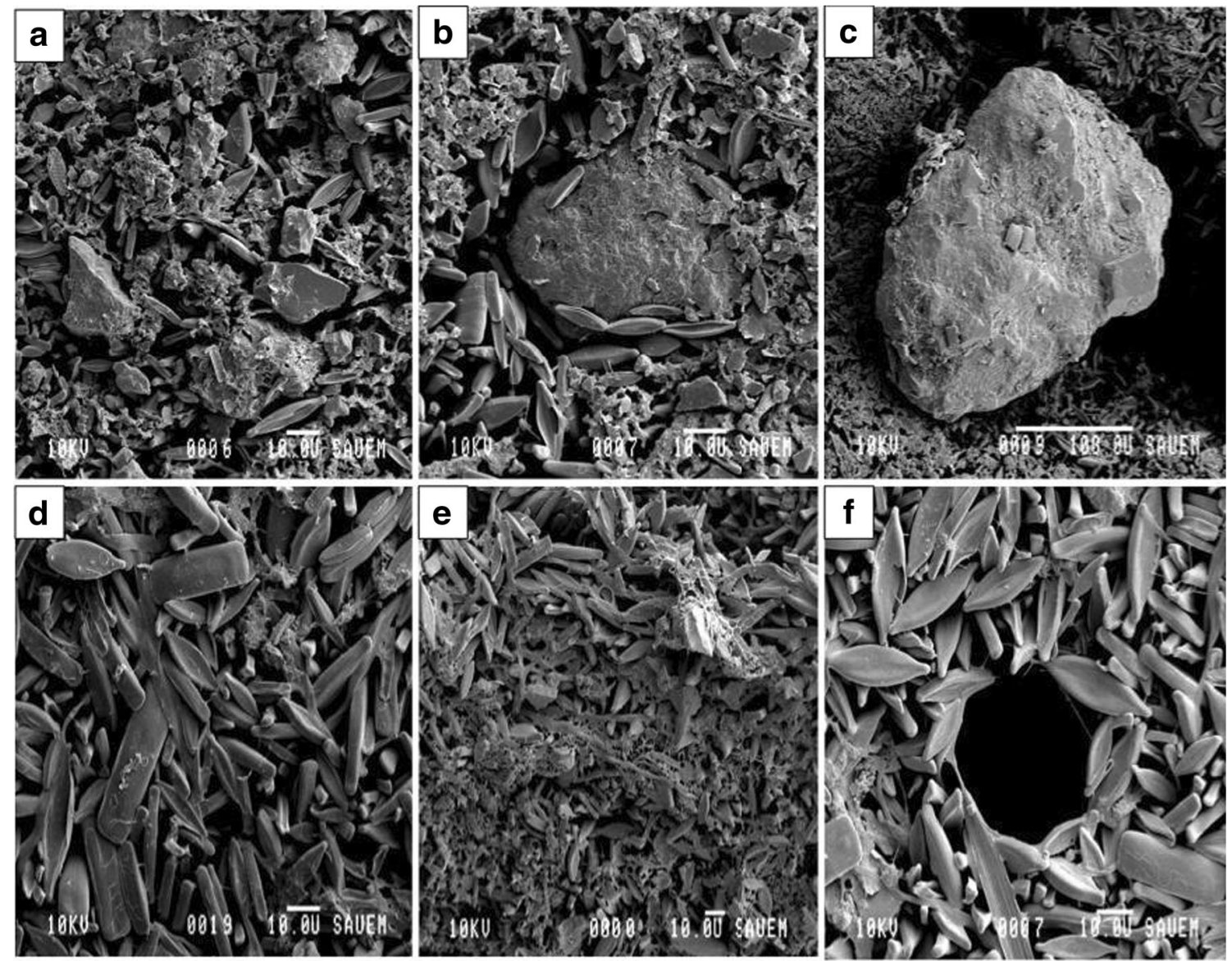

Fig. 2 Low temperature scanning electron micrographs from the surface of natural sediment from the Dee Estuary, UK. a-c Sandy sediment with associated diatoms. b, c Demonstrate variable colonisation of biofilm around individual sand grains. d, e A mixed sediment with more extensive diatom biofilm. d Surface, e fracture face and $\mathbf{f}$ possible worm hole into the sub-surface matrix. Image courtesy of COHBED and Irvine Davidson, University of St Andrews

effects of grazing and bioturbation by macrofauna necessitate that any evaluation of ecosystem function and service in response to multiple stressors can only meaningfully be done in the field. The imperative of addressing this question in a natural setting is compounded by the important role that physical factors play in determining sediment erosion potential, in some instances outweighing any relationship between sediment stability and the biota (Paterson et al. 2000; Defew et al. 2002; Tolhurst et al. 2002). In situ techniques, such as the use of the portable cohesive strength meter (CSM; Vardy et al. 2007; Grabowski et al. 2010) to measure relative erosion thresholds, allow the influence of multiple stressors on sediment stability to be quantified (Kenworthy et al. 2016). Through high-quality experimental designs, field experiments can therefore effectively test the application of additional stress. While field experiments are optimal for examining how a natural system reacts to stressors, they often lack the precision to isolate the mechanisms by which particular stressor impacts occur (Daehler and Strong 1996; Crane et al. 2007). For this reason, field and laboratory approaches are highly complementary. 


\section{Future work}

The next phase of research linked to biogenic effects is likely to rely on advances in molecular analysis, metagenomics (Thomas et al. 2012) and metabolomics (Nicholson and Lindon 2008) to assess the role of microbial assemblages in sediment behaviour. To date, prokaryotes (both archaebacteria and eubacteria) have largely been treated as a "black box" since only about $2 \%$ of known bacteria can be cultured (Wade 2002). However, even basic methodology may demonstrate the importance and flexibility of bacterial assemblages in terms of sediment dynamics, opening a new research avenue for emerging next generation technologies. Flow is an intrinsic component of estuarine, fluvial and coastal systems and as such should be taken into consideration when assessing ecosystem processes. Sediment erosion is induced by post-critical flow rates (or stresses), which cause particles to be lifted from the sediment bed and become suspended in the water column. These conditions regularly occur in estuarine systems in response to tidal action and river flow but we have little information on how this cycle of resuspension and deposition affects benthic bacteria assemblages and their metabolism. Microbial diversity has been successfully characterised in a wide variety of environments through amplification and sequence analysis of 16S rRNA genes (D'Amore et al. 2016). These techniques allow the characterisation of microbial communities, avoiding the problems associated with laboratory cultivation, and indicate that bacterial assemblages may respond rapidly to changes in environmental conditions (Currie et al. 2017). Biles et al. (2003) used laboratory mesocosms to investigate the response of bacterial communities to static or flow conditions. Sediments were eroded into suspension or kept at sub-critical flow and maintained on the bed. Analysis and clustering of the resultant RNA profiles demonstrated a consistent separation between the treatments, showing a rapid change in the activity once suspended in the flow (Fig. 3).

Now, metagenomic analysis of environmental DNA is helping to build a database of operational taxonomic units (OTUs, molecular analogue for species) that reveals the diversity of entire microbial assemblages in immense detail. In recent work, nearly 200,000 bacterial OTUs have been recorded from a laboratory incubation experiment using natural sediments (Hicks et al. pers. comm). Having to interpret this level of microbial biodiversity will become common in the next decade, but in itself will be of less interest than the study of the processes (metabolomics) that the bacterial assemblages drive (Nicholson and Lindon 2008). Part of this research will be the analysis of polymer production and secretion into the environment, as this medium is probably the major factor in mediating the response of the sediment to environmental forcing. Knowledge of how bacterial metabolism responds to environmental change, if driven by rapid evolutionary change (niche construction), will therefore become a driving force for environmental microbial ecology (Logue et al. 2015). There are, of course, other research themes beyond the scope of this current discussion including more precise determination of erosion dynamics in the laboratory and in the field, understanding of bed-flow interaction on a microscale and the better understanding of how natural mixed sediment beds behave under ambient flow conditions to name only a few. In addition, modelling is increasingly being developed (Hyder et al. 2015) to consider biological effects and ecohydraulic modelling is already attempting to bridge the gap between abiotic and biotic disciplines. However, the parametrisation of biotic influence (in space and time) remains an issue. To include the full life cycle and metabolic pathways of all relevant microorganisms (including nutrient turnover, oxygen dynamics,
Fig. 3 Diagrammatic neighbourjoining tree showing the relationship of bacterial assemblages from sediment samples in replicate chambers under flow and static conditions based on the analysis of aligned 16S rRNA sequences. The separation between static and flow conditions is almost complete (from Biles et al. 2003). Blue coloration indicates profiles from flow conditions while amber indicate profiles from static conditions. The two black bars are internal markers.

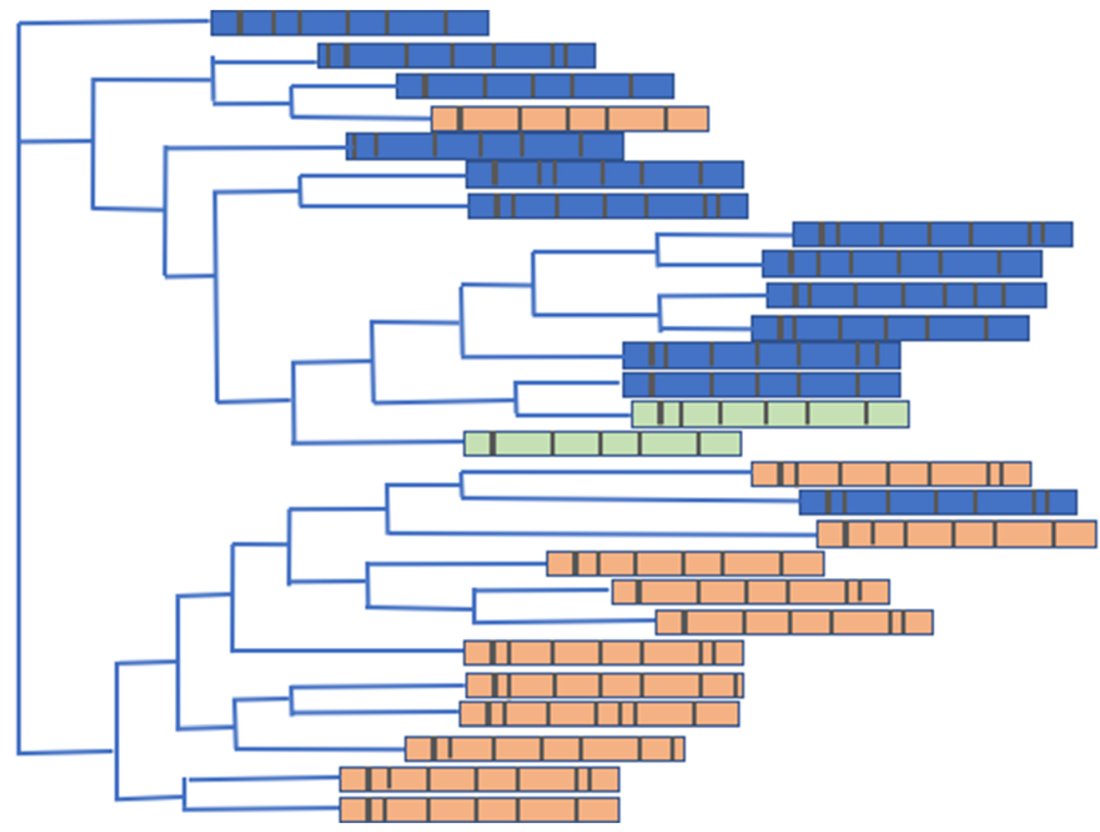


reproduction, etc.) would be overwhelming but can we parameterise biological effects in a helpful manner? This still requires considerable thought and may affect the design of future experiment since there is a clear challenge to consider how the physical biotic interplay affects all aspects of sediment dynamics.

\section{Conclusions}

There is a societal move away from solving all coastal and fluvial problems by hard engineering towards a more natural and ecosystem-based approach to coastal protection and flood mediation (Spalding et al. 2014). In terms of the coast, sea defences are often breached and new areas of salt marsh or mudflat are being encouraged or restored. For rivers, there is increasing recognition that channelised systems can exacerbate episodic extreme events and several projects have been initiated to reintroduce a more natural pattern of flow and upstream "storage" of waters to alleviate such extremes. This is essentially a form of "geo-engineering" that is enhanced by a healthy and resilient biotic component, and to fully understand how aquatic habitats will adjust to environmental change and to support the provision of various ecosystem services, we require a holistic approach. We must consider all aspects that control the distribution of sediment and the ETDC cycle, including biological physical and chemical processes. In particular, the role of microbial assemblages is now recognised as a significant factor deserving greater attention across disciplines.

Funding information JAH was supported by NERC award, COHBED (NE/1027223/1). DMP received funding from the MASTS pooling initiative (The Marine Alliance for Science and Technology for Scotland) and from the Extended Evolutionary Synthesis Research Program funded by the John Templeton Foundation and by NERC awards NE/J015644/ 1 and NE/N016009/1 - CBESS, and Blue Coast. MASTS is funded by the Scottish Funding Council (grant reference HR09011) and contributing institutions.

Open Access This article is distributed under the terms of the Creative Commons Attribution 4.0 International License (http:// creativecommons.org/licenses/by/4.0/), which permits unrestricted use, distribution, and reproduction in any medium, provided you give appropriate credit to the original author(s) and the source, provide a link to the Creative Commons license, and indicate if changes were made.

\section{References}

Aanensen DM, Feil EJ, MTG H, Dordel J, Yeats CA, Fedosejev A, Goater R, Castillo-Ramírez S, Corander J, Colijn C, Chlebowicz MA, Schouls L, Heck M, Pluister G, Ruimy R, Kahlmeter G, Åhman J, Matuschek E, Friedrich AW, Parkhill J, Bentley SD, Spratt BG, Grundmann H, European staphylococcal reference laboratory working group (2016) Whole-genome sequencing for routine pathogen surveillance in public health: a population snapshot of invasive Staphylococcus aureus in Europe. mBio 7(3):e00444-e0416
Altermann W (2008) Accretion, trapping and binding of sediment in archean stromatolites - morphological expression of the antiquity of life. Space Sci Rev 135:1-4

Altermann W, Józef K (2003) Archean microfossils: a reappraisal of early life on Earth. Res Microbiol 154(9):611-617

Alsterberg C, Sundback K, Gamfeldt L (2014) Multiple stressors and multifunctionality: limited effects on an illuminated benthic system. Biol. Lett. 10: 20140640. https://doi.org/10.1098/rsbl.2014.0640

Amos CL, Brylinsky M, Sutherland TF, O'Brien D, Lee S, Cramp A (1998) The stability of a mudflat in the Humber estuary, South Yorkshire, U.K. In: Black KS, Paterson DM, Cramp A (eds) Sedimentary processes in the intertidal zone. Geol. Soc. London, Special Publications, 139:25-43

Andersen TJ, Lanuru M, van Bernem C, Pejrup M, Riethmueller R (2010) Erodibility of a mixed mudflat dominated by microphytobenthos and Cerastoderma edule, East Frisian Wadden Sea, Germany. Estuar Coast Shelf Sci 87:197-206

Apitz SE, Elliott M, Fountain M, Galloway TS (2006) European environmental management: moving to an ecosystem approach. Integr Environ Assess Manag 2:80-85

Aspden RJ, Vardy S, Paterson DM (2004) Salt marsh microbial ecology: microbes, benthic mats and sediment movement. In: Fagherazzi S, Marani M, Blum LK (eds) The ecogeomorphology of tidal marshes. Am Geophy Union, Washington, DC. https://doi.org/10.1029/ CE059p0115

Beaumont NJ, Austen MC, Atkins J, Burdon D, Degraer S, Dentinho TP, Derous S, Holm P, Horton T, van Ierland E, Marboe AH, Starkey DJ, Townsend M, Zarzycki T (2007) Identification, definition and quantification of goods and services provided by marine biodiversity: implications for the ecosystem approach. Mar Pollut Bull 54:253-265

Biles CL, Solan M, Isaksson I, Paterson DM, Emes C, Raffaelli D (2003) Flow modifies the effect of biodiversity on ecosystem functioning: an in situ study of estuarine sediments. J Exp Mar Biol Ecol 285:165-177

Bishop MJ, Kelaher BP (2013) Context-specific effects of the identity of detrital mixtures on invertebrate communities. Ecol Evol 3:3986-3999

Black KS, Tolhurst TJ, Hagerthey SE, Paterson DM (2002) Working with natural cohesive sediments. J Hydraul Eng 128(1):1-7

Boogert NJ, Paterson DM, Laland KN (2006) The implications of niche construction and ecosystem engineering for conservation biology. Bioscience 57(7):570-578

Borsje BW, de Vries MB, Hulscher SJMH, de Boer GJ (2008) Modeling large-scale cohesive sediment transport affected by small-scale biological activity. Estuar Coast Shelf Sci 78(3):468-480

Bulling MT, Solan M, Dyson KE, Hernandez-Milian G, Luque P, Pierce GJ, Raffaelli D, Paterson DM, White PCL (2008) Species effects on ecosystem processes are modified by faunal responses to habitat composition. Oecologia 158:511-520

Chapman MG, Tolhurst TJ, Murphy RJ, Underwood AJ (2010) Complex and inconsistent patterns of variation in benthos, micro-algae and sediment over multiple spatial scales. Mar Ecol Prog Ser 398:33-47

Characklis WG, Marshall KC (eds) (1990) Biofilms. Wiley, New York

Chen XD, Zhang CK, Paterson DM, Thompson CEL, Townend IH, Gong Z, Zhou Z, Feng Q (2017) Hindered erosion: the biological mediation of non-cohesive sediment behaviour. Water Resour Res 53(6):4787-4801

Christensen MR, Graham MD, Vinebrooke RD, Findlay DL, Paterson MJ, Turner MA (2006) Multiple anthropogenic stressors cause ecological surprises in boreal lakes. Glob Chang Biol 12:2316-2322

Consalvey M, Paterson DM, Underwood GJC (2004) The ups and downs of life in a benthic biofilm: migration of benthic diatoms. Diatom Res 19(2):181-202

Crane M, Burton GA, Allen G, Culp JM, Greenberg MS, Munkittrick KR, Ribeiro R, Salazar MH, St-Jean SD (2007) Review of aquatic in situ approaches for stressor and effect diagnosis. Integr Environ Assess Manag 3:234-245

Currie AR, Tait K, Parry H, de Francisco-Mora B, Hicks N, Osborn AM, Widdicombe S, Stahl H (2017) Marine microbial gene abundance 
and community composition in response to ocean acidification and elevated temperature in two contrasting coastal marine sediments. Front Microbiol 8:1599

Daehler CC, Strong DR (1996) Can you bottle nature? The roles of microcosms in ecological research. Ecology 77:663-664

D'Amore R, Ijaz UZ, Schirmer M, Kenny JG, Gregory R, Darby AC, Shakya M, Podar M, Quince C, Hall N (2016) A comprehensive benchmarking study of protocols and sequencing platforms for $16 \mathrm{~S}$ rRNA community profiling. BMC Genomics 17:55

De Deckere EMGT, Tolhurst TJ, de Brouwer JFC (2001) Destabilisation of cohesive intertidal sediments by infauna. Estuar Coast Shelf Sci 56:665-669

Decrop B, De Mulder T, Toorman E, Sas M (2015) New methods for ADV measurements of turbulent sediment fluxes - application to a fine sediment plume. J Hydraul Res 53(3):317-331

Defew EC, Tolhurst TJ, Paterson DM (2002) Site-specific features influence sediment stability of intertidal flats. Hydrol Earth Syst Sci 6: 971-982

Droppo IG, Liss SN, Williams D, Nelson T, Jaskot C, Trapp B (2009) Dynamic existence of waterborne pathogens within river sediment compartments: implications for water quality regulatory affairs. Environ Sci Technol 43(6):1737-1743

Dyson KE, Bulling MT, Solan M, Hernandez-Milian G, Raffaelli DG, White PCL, Paterson DM (2007) Influence of macrofaunal assemblages and environmental heterogeneity on microphytobenthic production in experimental systems. Proc Biol Sci 274:2547-2554

Eisma D (1986) Flocculation and de-flocculation of suspended matter in estuaries. Neth J Sea Res 20:183-199

Fagherazzi S, Mariotti G, Banks AT, Morgan EJ, Fulweiler RW (2014) The relationships among hydrodynamics, sediment distribution, and chlorophyll in a mesotidal estuary. Estuar Coast Shelf Sci 144:54-64

Friend PL, Lucas CH, Holligan PM, Collins MB (2008) Microalgal mediation of ripple mobility. Geobiology 6:70-82

Gerbersdorf SU, Wieprecht S (2015) Biostabilization of cohesive sediments: revisiting the role of abiotic conditions, physiology and diversity of microbes, polymeric secretion, and biofilm architecture. Geobiology 13:68-97

Gerbersdorf SU, Jancke T, Westrich B (2007) Sediment properties for assessing the erosion risk of contaminated riverine sites. J Soils Sediments 7(1):25-35

Gerbersdorf SU, Bittner R, Lubarsky H, Manz W, Paterson DM (2009) Microbial assemblages as ecosystem engineers of sediment stability. J Soils Sediments 9(6):640-652

Gerbersdorf SU, Cimatoribus C, Class H, Engesser K-H, Helbich S, Hollert H, Lange C, Kranert M, Metzger JW, Nowak W, Seiler TB, Steger K, Steinmetz H, Wieprecht S (2015) Anthropogenic trace compounds (ATCs) in aquatic habitats - research needs on sources, fate, detection and toxicity to ensure timely elimination strategies and risk management. Environ Int 79:85-105

Godbold JA, Bulling MT, Solan M (2011) Habitat structure mediates biodiversity effects on ecosystem properties. Proc R Soc Lond Ser B Biol Sci 278:2510-2518

Graba M, Moulin FY, Boulêtreau S, Garabétian F, Kettab A, Eiff O, Sauvage S (2010) Effect of near-bed turbulence on chronic detachment of epilithic biofilm: experimental and modeling approaches. Water Resour Res 46(11). https://doi.org/10.1029/2009WR008679

Grabowski RC, Droppo IG, Wharton G (2010) Estimation of critical shear stress from cohesive strength meter-derived erosion thresholds. Limnol Oceanogr Methods 8:678-685

Grabowski RC, Droppo IG, Wharton G (2011) Erodibility of cohesive sediment: the importance of sediment properties. Earth Sci Rev 105: $101-120$

Hagadorn JW, McDowell C (2012) Microbial influence on erosion, grain transport and bedform genesis in sandy substrates under unidirectional flow. Sedimentology 59:795-808
Halpern BS, Walbridge S, Selkoe KA, Kappel CV, Micheli F, D'Agrosa C, Bruno JF, Casey KS, Ebert C, Fox HE, Fujita R, Heinemann D, Lenihan HS, Madin EMP, Perry MT, Selig ER, Spalding M, Steneck R, Watson R (2008) A global map of human impact on marine ecosystems. Science 319:948-952

Hannah DM, Wood PJ, Sadler JP (2004) Ecohydrology and hydroecology: a new paradigm? Hydrol Process 18:3439-3445

Hewitt JE, Thrush SF, Dayton PK, Bonsdorff E (2007) The effect of spatial and temporal heterogeneity on the design and analysis of empirical studies of scale-dependent systems. Am Nat 169:398-408

Hicks N, Bulling MT, Solan M, Raffaelli D, White PCL, Paterson DM (2011) Impact of biodiversity-climate futures on primary production and metabolism in a model benthic estuarine system. BMC Ecol 11:7

Hodl I, Mari L, Bertuzzo E, Suweis S, Besemer K, Rinaldo A, Battin TJ (2014) Biophysical controls on cluster dynamics and architectural differentiation of microbial biofilms in contrasting flow environments. Environ Microbiol 16:802-812

Hope JA (2016) The biological mediation of cohesive and non-cohesive sediment dynamics. Dissertation, University of St Andrews

Hyder K, Rossberg AG, Allen JI, Austen MC, Bannister HJ, Barciela RM, Blackwell PG, Blanchard JL, Burrows MT, Defriez E, Dorrington T, Edwards KP, Garcia-Carreras B, Heath MR, Hembury DJ, Heymans JJ, Holt J, Houle JE, Jennings S, Mackinson S, Malcolm SJ, McPike R, Mee L, Mills DK, Montgomery C, Pearson D, Pinnegar JK, Pollicino M, Popova EE, Rae LR, Rogers SI, Speirs D, Spence MA, Thorpe R, Turner RK, van der Molen J, Yool A, Paterson DM (2015) Making modelling count - increasing the contribution of shelf-seas community and ecosystem models to policy development and management. Mar Policy 61:291-302

Jones CG, Lawton JH, Shachak M (1994) Organisms as ecosystem engineers. Oikos 69:373-386

Kenworthy J, Paterson DM, Bishop MJ (2016) Response of benthic assemblages to multiple stressors: comparative effects of nutrient enrichment and physical disturbance. Mar Ecol Prog Ser 562:37-71

Koca K, Noss C, Anlanger C, Brand A, Lorke A (2017) Performance of the Vectrino profiler at the sediment-water interface. J Hydraul Res 55(4):573-581

Krumbein WE, Paterson DM, Stal, LJ (1994) Biostabilization of sediments. Carl von Ossietzky Universität Oldenburg, pp 526

Laland KN, Odling-Smee FJ, Feldman MW (1999) Evolutionary consequences of niche construction and their implications for ecology. PNAS 96:10242-10247

Le Hir P, Monbet Y, Orvain F (2007) Sediment erodability in sediment transport modelling: can we account for biota effects? Cont Shelf Res 27:1116-1142

Lick W, Jin L, Gailani J (2004) Initiation of movement of quartz particles. J Hydraul Eng 130(8):755-761

Logue JB, Findlay SEG, Comte J (2015) Editorial: microbial responses to environmental changes. Front Microbiol 6:1364

Lubarsky HV, Hubas C, Chocholek M, Larson F, Manz W, Paterson DM, Gerbersdorf SU (2010) The stabilisation potential of individual and mixed assemblages of natural bacteria and microalgae. PLoS One 5(11): 13794

Malarkey J, Baas JH, Hope JA, Aspden RJ, Parsons DR, Peakall J, Paterson DM, Schindler RJ, Ye L, Lichtman ID, Bass SJ, Davies AG, Manning AJ, Thorne PD (2015) The pervasive role of biological cohesion in bedform development. Nat Commun 6:6257

Manning AJ, Baugh JV, Spearman JR, Whitehouse RJ (2010) Flocculation settling characteristics of mud: sand mixtures. Ocean Dyn 60(2):237-253

Manz B, Volke F, Goll D, Horn H (2005) Investigation of biofilm structure, flow patterns and detachment with magnetic resonance imaging. Water Sci Technol 52(7):1-6 
Manzenrieder H (1983) Retardation of initial erosion under biological effects in sandy tidal flats. Dissertation, Leichtweiss Inst Tech Univ, Braunschweig, pp 469-479

Meadows PS, Anderson JG (1969) Micro-organisms attached to marine sand grains. J Mar Biol Assoc UK 48(01):161-175

Mietta F, Chassagne C, Manning AJ, Winterwerp JC (2009) Influence of shear rate, organic matter content, $\mathrm{pH}$ and salinity on mud flocculation. Ocean Dyn 59:751-763

Möller I, Kudella M, Rupprecht F, Spencer T, Paul M, van Wesenbeeck BK, Wolters G, Jensen K, Bouma TJ, Miranda-Lange M, Schimmels S (2014) Wave attenuation over coastal salt marshes under storm surge conditions. Nat Geosci 7:727-731

Moulin F, Eiff O (2012) Biofilms, hydraulics and sediment dynamics, HYDRALAB-IV Deliverable D7.1, EC contract no. 261520

Nicholson JK, Lindon JC (2008) Systems biology: metabonomics. Nature 455(7216):1054-1056

Noffke N, Paterson DM (2008) Microbial interactions with physical sediment dynamics, and their significance for the interpretation of Earth's biological history. Geobiology 6:1-4

Nowell ARM, Jumars PA, Eckman JE (1981) Effects of biological activity on the entrainment of marine sediments. Mar Geol 42:133-153

Orvain F, Sauriau P-G, Bacher C, Prineau M (2006) The influence of sediment cohesiveness on bioturbation effects due to Hydrobia ulvae on the initial erosion of intertidal sediments: a study combining flume and model approaches. J Sea Res 55:54-73

Pachepsky YA, Shelton DR (2011) Escherichia coli and fecal coliforms in freshwater and estuarine sediments. Crit Rev Environ Sci Technol 4112:1067-1110

Parchure TM, Mehta AJ (1985) Erosion of soft cohesive sediment deposits. J Hydol Eng 111:1308-1326

Parsons DR, Schindler RJ, Hope JA, Malarkey J, Baas JH, Peakall J, Manning AJ, Ye L, Simmons S, Paterson DM (2016) The role of biophysical cohesion on subaqueous bedform size. Geophys Res Lett 43:1566-1573

Passarelli C, Olivier F, Paterson DM, Hubas C (2012) Impacts of biogenic structures on benthic assemblages: microbes, meiofauna, macrofauna and related ecosystem functions. Mar Ecol Prog Ser 456:85-97

Paterson DM (1994) Microbiological mediation of sediment structure and behaviour. In: Caumette P, Stal LJ (eds) Microbial mats. NATO ASI Series 35:97-109

Paterson DM (1997) Biological mediation of sediment erodibility: ecology and physical dynamics. In: Burt N, Parker R, Watts J (eds) Cohesive sediments. Wiley, pp 215-229

Paterson DM, Black KS (1999) Water flow, sediment dynamics, and benthic biology. In: Raffaelii D, Nedwell D (eds) Adv Ecol Res. Oxford Univ Press, Oxford, pp 155-193

Paterson DM, Tolhurst TJ, Kelly JA, Honeywill C, de Deckere EMGT, Huet V, Shayler SA, Black KS, de Brouwer J, Davidson I (2000) Variations in sediment properties, Skeffling mudflat, Humber estuary, UK. Cont Shelf Res 20:1373-1396

Paterson DM, Aspden RJ, Visscher PT, Consalvey M, Andres MS, Decho AW, Stolz J, Reid RP (2008) Light-dependant biostabilisation of sediments by stromatolite assemblages. PLoS One 3(9):3176

Pereira MO, Kuehn M, Wuertz S, Neu T, Melo LF (2002) Effect of flow regime on the architecture of a Pseudomonas fluorescens biofilm. Biotechnol Bioeng 78:164-171

Rice SP, Little S, Wood PJ, Moir HJ, Vericat D (2010) The relative contributions of ecology and hydraulics to ecohydraulics. River Res Appl 26:363-366

Righetti M, Lucarelli C (2007) May the Shields theory be extended to cohesive and adhesive benthic sediments? J Geophys Res 112(C5). https://doi.org/10.1029/2006JC003669

Schindler RJ, Parsons DP, Ye L, Hope J, Baas JH, Peakall J, Manning AJ, Aspden RJ, Malarkey J, Simmons S, Paterson DM, Lichtman I, Davies AG, Thorne PD, Bass S (2015) Sticky stuff: redefining bedform prediction in modern and ancient environments. Geology 43(5):399-402

Schmidt H, Thom M, Matthies K, Behrens S, Obst U, Wieprecht S, Gerbersdorf SU (2015) A multi-disciplinarily designed mesocosm to address the complex flow-sediment-ecology tripartite relationship on the microscale. Environ Sci Eur 27:2

Schmidt H, Thom M, King L, Wieprecht S, Gerbersdorf SU (2016) The effect of seasonality upon the development of lotic biofilms and microbial biostabilisation. Freshw Biol 61:963-978

Shields A (1936) Anwendung der Ähnlichkeitsmechanik und der Turbulenzforschung auf die Geschiebebewegung. In: Mitteilungen der Preussischen Versuchsanstalt für Wasserbau und Schiffbau, Heft 26

Spalding MD, McIvor AL, Beck MW, Koch EW, Möller I, Reed DJ, Rubinoff P, Spencer T, Tolhurst TJ, Wamsley TV, van Wesenbeeck BK, Wolanski E, Woodroffe CD (2014) Coastal ecosystems: a critical element of risk reduction. Conserv Lett 7:293-301

Spencer T, Möller I, Rupprecht F, Bouma TJ, van Wesenbeeck BK, Kudella M, Paul M, Jensen K, Wolters G, Miranda-Lange M, Schimmels S (2016) Salt marsh surface survives true-to-scale simulated storm surges. Earth Surf Process Landf 41:543-552

Sutherland TF, Amos CL, Grant J (1998) The effect of buoyant biofilms on the erodability of sublittoral sediment of a temperate microtidal estuary. Limnol Oceanogr 43:225-235

Thom M, Schmidt H, Gerbersdorf SU, Wieprecht S (2015) Seasonal biostabilisation and erosion behaviour of fluvial biofilms under different hydrodynamic and light conditions. Int J Sediment Res 30: 273-284

Thomas T, Gilbert J, Meyer F (2012) Metagenomics - a guide from sampling to data analysis. Microb Inf Exp 2:3

Thrush SF, Halliday J, Hewitt JE, Lohrer AM (2008) The effects of habitat loss, fragmentation and community homogenization on resilience in estuaries. Ecol Appl 18(1):12-21

Tolhurst TJ, Gust G, Paterson DM (2002) The influence of an extracellular polymeric substance (EPS ) on cohesive sediment stability. Proc Mar Sci 5:409-425

Tolhurst TJ, Friend PL, Watts C, Wakefield R, Black KS, Paterson DM (2006) The effects of rain on the erosion threshold of intertidal cohesive sediment. Aquat Ecol 40(4):533-541

Tolhurst TJ, Consalve M, Paterson DM (2008) Changes in cohesive sediment properties associated with the growth of a diatom biofilm. Hydrobiologia 596:225-239

Tolhurst TJ, Black KS, Paterson DM (2009) Muddy sediment erosion: insights from field studies. J Hydrol Eng 135(2):73-87

Unadkat H, Rielly CD, Hargrave GK, Nagy ZK (2009) Application of fluorescent PIV and digital image analysis to measure turbulence properties of solid-liquid stirred suspensions. Chem Eng Res Des 87(4):573-586

Vardy S, Saunders JE, Tolhurst TJ, Davies P, Paterson DM (2007) Calibration of the high-pressure cohesive strength meter (CSM). Cont Shelf Res 27:1190-1199

Vignaga E, Haynes H, Sloan WT (2012) Quantifying the tensile strength of microbial mats grown over noncohesive sediments. Biotechnol Bioeng 109:1155-1164

Violeau D (2012) Fluid mechanics and the SPH method: theory and applications. Oxford, pp 593

Wade W (2002) Unculturable bacteria - the uncharacterised organisms that cause oral infections. J R Soc Med 95(2):81-83

Wagner M, Manz B, Volke F, Neu TR, Horn H (2010) Online assessment of biofilm development, sloughing and forced detachment in tube reactor by means of magnetic resonance microscopy. Biotechnol Bioeng 107:172-181

Wheatland JAT, Bushby AJ, Spencer KL (2017) Quantifying the structure and composition of flocculated suspended particulate matter using focused ion beam nanotomography. Environ Sci Technol 51(16): $8917-8925$ 